Historia Slavorum Occidentis

2021, nr 4 (31)

ISSN 2084-1213

DOI: $10.15804 /$ hso210407

\author{
Jędrzej Paszkiewicz (Poznań)
}

ORCID: 0000-0002-7115-9284

\title{
Węgry w działalności chorwackiego ruchu ustaszy (1929-1934)
}

Keywords: Ustasha movement, Hungary, Yugoslavia, Janka-Puszta, terrorism

Słowa kluczowe: ustasze, Węgry, Jugosławia, Janka-Puszta, terroryzm

\begin{abstract}
Hungary's role in the activity of the Ustasha - Croatian Revolutionary Movement (1929-1934). The Ustasha (Ustaša) movement developed in Hungary, establishing its cadre organisation framework, seeking the support of Croatian migrant communities and training task forces in diversion and terrorist tactics. Following their disclosure, however, they were no longer supported by the Hungarian authorities.
\end{abstract}

Węgry stanowiły naturalny cel, gdy mowa o próbach zdobycia wsparcia politycznego, militarnego i finansowego przez emigracyjny ruch separatystów chorwackich, który formował się od początku 1929 r. W państwie tym działały środowiska, powiązane $z$ establishmentem politycznym i siłami wojskowo-policyjnymi, zainteresowane wspieraniem sabotażowej oraz terrorystycznej działalności rozmaitych grup antyjugosłowiańskich. Przedstawiciele tych grup odwoływali się do kilkusetletniej historii współistnienia Węgrów i Chorwatów w ramach tzw. unii państwowej, której początki, na poły legendarne, sięgały XII w. Silne były wśród nich sentymenty austrowęgierskie, przy ich okazji powoływano się na wielowiekową tradycję tzw. sejmu węgiersko-chorwackiego czy okres, gdy ziemie chorwackie dysponowały ograniczoną autonomią w ramach węgierskiej części monarchii (1868-1918) ${ }^{1}$.

1 Zarys relacji chorwacko-węgierskich do końca pierwszej wojny światowej: L. Heka, Hrvat- 
Z kolei z punktu widzenia polityki węgierskiej, Jugosławia (nazywana do października 1929 r. Królestwem Serbów, Chorwatów i Słoweńców) stanowiła jedną z przeszkód dla odzyskania ziem, które Węgry straciły w następstwie klęski wojennej oraz postanowień traktatu pokojowego z Trianon (4 VI 1920). Dla rewizjonistycznych środowisk w Budapeszcie separatystyczna organizacja ustaszy mogła być skutecznym narzędziem nacisku na sąsiednie państwo, zwłaszcza że jej liderzy poszukiwali za granicą wsparcia finansowego, logistycznego oraz politycznego ${ }^{2}$. $\mathrm{Z}$ drugiej strony jednak, wśród środowisk węgierskich brakowało zdecydowanej woli politycznej, aby jednoznacznie wspierać antyjugosłowiańskie działania środowisk chorwackich. Przeważała opinia o konieczności spokojnego rozwijania relacji z Jugosławią, zwłaszcza w obliczu sporów terytorialnych, które angażowały uwagę Węgier w relacjach z pozostałymi sąsiadami: Czechosłowacją i Rumunią. Ostatecznie, w węgierskim stosunku do jugosłowiańskiego sąsiada uzewnętrzniła się swoista ambiwalencja, wynikająca z ówczesnej izolacji geopolitycznej kraju. Z jednej strony w Budapeszcie myślano o uspokojeniu stosunków z Jugosławią, aby osłabić antywęgierskie ostrze Małej Ententy. Z drugiej strony, spoglądano w kierunku Włoch, których polityka była nastawiona na tworzenie bloku państw rewizjonistycznych w Europie Środkowej (naddunajkkiej) i wymierzona w integralność terytorialną Jugosławii ${ }^{3}$. W oparciu o współpracę z Włochami władze węgierskie starały się też konkretyzować swój stosunek zarówno do spraw chorwackich, jak i ruchu ustaszy ${ }^{4}$.

Bez wątpienia, obecność chorwackich separatystów była na Węgrzech zauważana przez przedstawicieli środowisk państwowych. Jak pisał jesienią 1928 r. w liście do

sko-ugarski odnosi od srednjega vijeka do Nagodbe iz 1868. s posebnim osvrtom na pitanje Slavonije, Scrinia Slavonica. Godišnjak Podružnice za povijest Slavonije, Srijema i Baranje 8 (2008), s. 152-173. O różnych aspektach chorwackiego statusu prawno-politycznego w ramach węgierskiej części monarchii habsburskiej traktuje zbiorowa publikacja: A horvát-magyar együttélés fordulópontjai. Intézmények, társadalom, gazdaság, kultura, red. P. Fodor, D, Šokčević, J. Turkalj, D. Karbić, Budapest 2015.

2 Na temat międzynarodowego kontekstu aktywności ruchu ustaszy m.in. J. Paszkiewicz, Terrorism in service of the Croatian independence. The international connections of the Croatian separatists (1929-1941), [w:] Europa Środkowa i Batkany. Konteksty historyczne i politologiczne, red. M. Korzeniewska-Wiszniewska, A. Kastory, R. Woźnica, Kraków 2019, s. 343-359. 3 Por. V. Vinaver, Jugoslavija i Mađarska 1918-1933, Beograd 1977, s. 23-28; A. Hornjak, Susreti i sukobi. Ogledi o srpsko-mađarskim odnosima, Beograd 2017, s. 163-167.

4 O stanowisku węgierskiej historiografii na temat wspierania ruchu ustaszy przez Węgry pisał m.in. M. Ormos, Merénylet Marseille-ben, Budapest 1984; por. także D. Sokcsevits, Horvátország a 7. századtól napjainkig, Budapest 2011, s. 492-496. 
włoskiego ambasadora w Belgradzie Carla Galliego jego węgierski odpowiednik Pál Forster, środowiska chorwackie należało poważnie wziąć pod uwagę, nawet jeśli nie były one w stanie wzniecić żadnej poważniejszej rewolucji narodowej przeciwko Jugosławii czy zagrozić jej istnieniu. Włoski dyplomata odniósł wówczas wrażenie, że rząd węgierski nie chciał aktywnie wspierać separatystów, ponieważ obawiał się komplikacji międzynarodowych, a zwłaszcza wspólnych działań ze strony Małej Ententy. Dodajmy, że takiej możliwości nie widziały w ówczesnym czasie także i Włochy ${ }^{5}$. Węgierska dyplomacja starała się jednak wykorzystywać sprawę chorwacką $\mathrm{w}$ rozgrywkach politycznych. Jej przedstawiciele monitorowali poczynania ustaszy działających w Austrii i Niemczech, oferowali Włochom pośrednictwo w nieformalnych kontaktach z liderami ruchu, na czele z Ante Paveliciem. W obliczu poważnego kryzysu politycznego w Królestwie SHS, w październiku 1928 r., premier węgierski Lajos Walko zaproponował Benicie Mussoliniemu konsultacje w sprawie chorwackiej, która w jego opinii miała żywotne znaczenie dla polityki obu państw w regionie naddunajskim 6 . Z kolei 23 VII 1929 r. A. Pavelić spotkał się w Bolonii z węgierskim dyplomatą Gáborem Aporem, który w imieniu swojego rządu zadeklarował wsparcie finansowe i „moralne” dla organizowanego ruchu. W następstwie fiaska prób zorganizowania ustaszowskiego powstania w Lice (6-7 IX 1932; Lički/Velebitski ustanak), w listopadzie 1932 r. węgierski premier Gyula Gömbös i Benito Mussolini uznali w Rzymie, że należało tak skoordynować współpracę węgiersko-włoską, aby skuteczniej wykorzystać środowisko ustaszy do działań wymierzonych w Jugosławię? . Politycy mieli wówczas dojść do porozumienia m.in. w sprawie wspierania działalności specjalnych obozów dla uchodźców/imigrantów chorwackich, które szkoliły pod kątem prowadzenia akcji sabotażowo-dywersyjnych. Na Węgrzech taki obóz funkcjonował już od połowy 1931 r. w hrabstwie Somogy, w przygranicznej miejscowości Janka-Puszta. Jego twórcą był Gustav Perčec, powiązany z liderem ruchu Ante Paveliciem, działający na Węgrzech pod nazwiskiem Emil Horvát ${ }^{8}$. Celem

5 Archivio Storico Diplomatico del Ministero degli Affari Esteri, Roma, Affari Politici 1919-1930, Jugoslavia (dalej ASD, AP 1919-1930 Jug.), (dalej ASD, AP 1919-1930 Jug.), teczka 1341 (24 IX 1928).

6 Documenti Diplomatici Italiani (dalej DDI), VII seria, t. 7, dok. nr 43 (17.10.1928) ASD, AP 1919-1930, Jug., teczka 1341 (23 X 1928).

7 P. Hamerli, The Hungarian-Italian support of the Croatian separatism between 1928 and 1934, West Bohemian Historical Review 5 (2015), nr 1, s. 60; E. Gobetti, Dittatore per caso: un piccolo duce protetto dall'Italia fascista, Napoli 2001, s. 46.

8 W czasach austrowęgierskich Gustav Perčec był oficerem łącznikowym armii habsburskiej. 
zorganizowania bazy ekonomicznej dla tego przedsięwzięcia, latem 1931 r. G. Perčec zakupił dom i ziemię uprawną w miejscowości Nagykanizsa. Stopniowo pojawili się tam kolejni stronnicy ustaszy, z czasem podjęto działalność szkoleniową i propagandową. Dokupiono kolejne parcele, które wykorzystano do prac rolnych i szkoleń o charakterze parawojskowym (w sumie ponad 95 hektarów). Nie wiadomo, z jakich źródeł finansowano kupno tych nieruchomości. W literaturze historycznej dominuje pogląd, że G. Perčec mógł w tej kwestii liczyć na wsparcie ze strony miejscowych środowisk węgierskich, powiązanych $\mathrm{z}$ administracją i wojskiem ${ }^{9}$.

W następstwie zamachu króla Aleksandra (6 I 1929) do Węgier wyemigrowała spora część zwolenników separatyzmu chorwackiego. Część traktowała kierunek węgierski jako tymczasowy, udając się następnie do krajów Europy Zachodniej lub migrując do Ameryki Południowej (Argentyna, Urugwaj). Skład społeczny imigrantów był zróżnicowany. W dużej części byli wśród nich studenci, inteligencja czy wojskowi, którzy służyli jeszcze w armii austrowęgierskiej, zdarzali się właściciele ziemscy. Należy podkreślić, że spora część chorwackich imigrantów, przebywających wówczas na Węgrzech, znalazła się tam jeszcze przed 1929 r. Migracje odbywały się od chwili proklamowania Królestwa SHS w 1918 r. Przybysze z ziem chorwackich żyli na Węgrzech w rozproszeniu, najczęściej w południowej części kraju ${ }^{10}$. Trudno w tym wypadku o precyzyjne statystyki. Nie sposób ustalić także, nawet szacunkowo, liczby emigrantów związanych ze środowiskami chorwackich separatystów ${ }^{11}$. Jak

Władze jugosłowiańskie śledziły jego poczynania od 1921 r., odnotowując działalność w chorwackich środowiskach politycznych na Węgrzech. W 1929 r. G. Perčec, w charakterze współpracownika A. Pavelicia, uczestniczył w spotkaniu z przedstawicielami antyjugosłowiańskiego ruchu macedońskiego (VMRO) w Sofii. W tym samym czasie, z racji zaangażowania w aktywność ruchu ustaszy, został skazany w Jugosławii na karę śmierci; ASD, AP 1919-1930, Bulgaria, teczka 927 (24 IV 1929).

9 Większą część gruntów G. Perčec zakupił od Gyuli Szájbélyego, posługując się fałszywymi personaliami. Początkowo rozważał on kupno działki w rejonie Sopronu, ale ostatecznie zdecydował się na okolice Nagykanizsa, jako że znajdowały się blisko granicy i jednocześnie leżały na uboczu głównych szlaków komunikacyjnych; B. Krizman, Ante Pavelić i ustaše, Zagreb 1986, s. 102, 207.

10 Archivio Centrale dello Stato, Ispettore Generale di Pubblica Sicurezza. Carte Conti, Roma (dalej ACS, Carte Conti), teczka 3/19. Wedle wiedzy włoskich władz większe skupiska Chorwatów znajdowały się w Budapeszcie, Hódmezővásárhely, Szeged, Gyékényes, Kaposvár, Pécs i Zalaegerszeg.

11 W historiografii jugosłowiańskiej akcentowane jest przekonanie, że w większość decyzji o emigracji podejmowanych przez Chorwatów miała podłoże ekonomiczne, a nie polityczne; V. Vinaver, Jugoslavija i Mađarska, s. 145. 
wynika z raportu włoskiego inspektora MSZ Ercole Contiego, odpowiedzialnego za organizację ustaszowskich obozów na terenie Włoch (14 IV 1934), w pierwszym kwartale 1934 r. władze jugosłowiańskie poszukiwały lub prowadziły działania śledcze w przypadku 367 osób przebywających na terytorium Węgier. Blisko 60 osób identyfikowano ze środowiskiem Gustava Perčeca, przy czym nie byli to wyłącznie ustasze. Przeważająca większość uwzględnionych w rejestrze (ponad 200), przebywających wedle wiedzy władz jugosłowiańskich na Węgrzech, była poszukiwana z powodu dezercji lub szpiegostwa. Ponad 80 osób śledzono w związku z ich ogólnie nakreśloną działalnością polityczną, skierowaną przeciwko interesom Jugosławii. 24 osobom zarzucano wspieranie radykalnych organizacji separatystycznych, 16 oskarżano o zabójstwa, nie tylko polityczne, a dziewięć poszukiwano za działalność terrorystyczną. Na dziesięciu poszukiwanych ciążyły zarzuty prowadzenia propagandy antyjugosłowiańskiej i przemytu broni. Opierając się na tych danych, należy uznać, że środowiska proustaszowskie, działające na Węgrzech na przełomie lat dwudziestych i trzydziestych XX w., były nieliczne i miały charakter kadrowy. Ich ówczesna aktywność musiała być systematycznie zasilana przez działaczy organizacji przysyłanych z Włoch lub Austrii ${ }^{12}$.

Ze szczątkowych danych, ujawnionych przez E. Contiego wyłania się duże zróżnicowanie ideowe imigracji politycznej, identyfikowanej z chorwackim nacjonalizmem. Najwięcej określonych pod względem przynależności organizacyjnej imigrantów było powiązanych z prowęgierskim towarzystwem o nazwie Hrvatska legija, założonym przez grupę imigrantów w Zalaegerszeg, w południowo-zachodniej części kraju. Organizacja działała wyłącznie na terytorium węgierskim. W jej skład wchodzili dezerterzy z armii jugosłowiańskiej, część pełniła służbę jeszcze w wojsku habsburskim, inni zaciągnęli się do służby w armii węgierskiej. Na Węgrzech działała także organizacja Hrvatski domobran, którą stworzyli w Zagrzebiu w 1928 r. działacze Związku Republikańskiej Omladiny Prawaszy (SHPRO; Savez Hrvatske Pravaške Republikanske Omladine). Rozwiązany przez władze jugosłowiańskie w 1929 r., odrodził się on na bazie chorwackich środowisk emigranckich w Europie i obu Ame-

12 ACS, Carte Conti. Interesująca jest także dysproporcja, przytoczona w raporcie C. Contiego, pomiędzy liczbą imigrantów osiedlonych na Węgrzech (367 osób) i we Włoszech (92 osoby). Węgry były częściej wybierane przez polityczną emigrację chorwacką jako kierunek wyjazdu z racji bliższych kontaktów społecznych czy ekonomicznych, pochodzących z czasów habsburskich. Ponadto część sympatyków ruchu traktowała Włochy z dystansem ze względu na to, że włoski rewizjonizm zakładał przejęcie kontroli nad sporą częścią chorwackiego terytorium narodowego i historycznego (Dalmacja, wybrzeże adriatyckie); por. J. Paszkiewicz, Jugosławia w polityce Włoch w latach 1914-1941, Poznań 2004, s. 123. 
rykach. Część jej działaczy związała się z ruchem ustaszy. Prowęgiersko nastawieni imigranci działali w skrajnie nacjonalistycznym ruchu polityczno-militarnym o nazwie Unia Odrodzenia Węgrów (ÉME; Ébredő Magyarok Egyesülete), kojarzonym $\mathrm{z}$ aktywnością bojówkarską. Choć związane z nim formacje paramilitarne zostały zakazane przez władze w 1922 r., polityczne wpływy tego środowiska były zauważalne w ówczesnej przestrzeni publicznej, chociażby w związku z deklarowanym przez jego liderów antysemityzmem ${ }^{13}$. Chorwaccy imigranci, przebywający na Węgrzech, często byli także powiązani z węgierskimi służbami wywiadowczymi, które wykorzystywały ich powiązania rodzinne i dobrą orientację w sprawach polityki jugosłowiańskiej. W tej grupie znaną postacią był Josip Metzger (1883-1945), były oficer austro-węgierski, który w 1919 r. uczestniczył w nieudanej próbie przewrotu komunistycznego w Zagrzebiu (afera Diamantstein; 1919-1920). Następnie osiadł w Budapeszcie, gdzie był zatrudniony w sekcji wywiadu węgierskiego ministerstwa obrony i współpracował w charakterze łącznika z rzecznikami chorwackiego separatyzmu. Był także członkiem kadry w ustaszowskim obozie w Janka-Puszta, odpowiadał tam za szkolenia polityczne i działalność propagandową ${ }^{14}$.

Za najważniejszą postać chorwackiej imigracji politycznej na Węgrzech uznaje się jednak Iva Franka (1877-1939), działacza Chorwackiej Partii Prawa (Hrvatska stranka prava). Jeszcze w czasach habsburskich zajmował on stanowisko antywęgierskie. Zmienil poglądy w 1918 r., protestując przeciwko stworzeniu Królestwa SHS. Na początku lat dwudziestych rozwijał propagandę antyjugosłowiańską na łamach prasy węgierskiej, starał się mobilizować miejscowe grupy imigrantów i popularyzować postulaty chorwackiego nacjonalizmu wśród środowisk węgierskich w $\mathrm{Bu}$ dapeszcie ${ }^{15}$. I. Frank cieszył się dużym autorytetem wśród tamtejszych Chorwatów, zwłaszcza tych, którzy identyfikowali się z nacjonalistyczną organizacją Hrvatski domobran. Informatorzy policji jugosłowiańskiej uznawali go wręcz za lidera węgierskiego skrzydła tej organizacji, chociaż według źródeł węgierskich miał on porzucić aktywną działalność polityczną już na początku lat dwudziestych ${ }^{16}$.W 1928 r. przyjął

13 P. Hamerli, Croatian political refugees living in emigration in the interwar period: the case of the Croatian political refugees in Hungary, Hungarian Historical Review 6 (2017), nr 3, s. 636-637.

14 B. Krizman, Ante Pavelić, s. 204-205; N. Bartulin, The Racial idea in the Independent State of Croatia, Leiden-Boston 2014, s. 98.

15 DDI, 7 seria, t. 7, dok. nr 41 (16 X 1928).

16 B. Krizman, Ante Pavelić, s. 176; S. Matković, Prilozi za politički životopis Ive Franka i evoluciju pravaštva, Časopis za suvremenu povijest 40 (2008), nr 3, s. 1081. 
jednak propozycję kooperacji z Ante Paveliciem, który po opuszczeniu Królestwa SHS szukał wsparcia za granicą, za pośrednictwem chorwackich środowisk z Austrii i Węgier. Bez wątpienia współpraca ta przysłużyła się popularyzacji postulatów ustaszy wśród tzw. węgierskich Chorwatów. Drogi obu polityków miały się rozejść na przełomie lat 1928 i 1929, gdy A. Pavelić wyznaczył na głównego przedstawiciela ustaszy na Węgrzech Gustava Perčeca ${ }^{17}$.

Pod koniec 1928 r. A. Pavelić i I. Frank z sympatią wypowiadali się, przy okazji nieoficjalnych kontaktów z przedstawicielami władz, o rewizjonizmie węgierskim oraz włoskim. Podkreślali znaczenie Węgier i Włoch w dookreślaniu postulatów oraz ram organizacyjnych chorwackiego nacjonalizmu. Sygnalizowali gotowość współpracy z państwem węgierskim na rzecz wolnej Chorwacji, co jednak nie zaowocowało jednoznacznym wsparciem politycznym czy finansowym ze strony kół rządowych ${ }^{18}$. Gdy w 1931 r. Gustav Perčec, podwładny A. Pavelicia, przystąpił do organizowania bazy ustaszy przy granicy węgiersko-jugosłowiańskiej, musiał polegać na prywatnych kontaktach i nieformalnych uzgodnieniach z poszczególnymi przedstawicielami węgierskich kół administracyjnych oraz policyjnych. Sytuacja ta zmieniła się na przełomie 1932 i 1933 r., gdy w następstwie uzgodnień pomiędzy B. Mussolinim i G. Gömbösem ośrodek Janka-Puszta został uwzględniony w ogólniejszych planach rewizjonizmu węgierskiego oraz włoskiego.

Pierwsi imigranci pojawili się w Janka-Puszta w październiku 1931 r., ale do końca roku obóz nie funkcjonował jako ośrodek szkoleniowo-dywersyjny. W zamyśle A. Pavelicia, celem tej bazy było uformowanie kadry złożonej z bojowników lojalnych wobec ustaszowskiego dowództwa, odpowiedzialnych za utrzymywanie kontaktów z ziemiami chorwackimi oraz prowadzenie działalności terrorystycznej przeciwko Jugosławii. Myślał on także o zacieśnianiu kontaktów z innymi antyjugosłowiańsko nastawionymi ruchami separatystycznymi bądź irredentystycznymi, chociażby z ruchem macedońskim ${ }^{19}$. Wszystkie osoby związane z obozem miały być objęte restrykcyjnymi procedurami dostępu, w stosunku do mężczyzn stale przebywających w bazie zastosowano kilkustopniową procedurę kwalifikacyjną. Najpierw zbiegowie z Jugosławii byli selekcjonowani przez przedstawicieli władz węgierskich, które bazę w Janka-Puszta oficjalnie uznawały za obóz dla uchodźców. Następnie

17 J. Jareb, Šest dokumenata o prvom dodiru dra Ante Pavelića s talijanskom vladom 1927, Hrvatska revija 4 (1970), s. 1166; E. Gobetti, Dittatore per caso, s. 23.

18 P. Hamerli, The Hungarian-Italian support, s. 56.

19 B. Krizman, Ante Pavelić, s. 166. 
osoby te były przesłuchiwane przez policję pod kątem ich powiązań z wywiadem jugosłowiańskim czy ruchem komunistycznym. Po pozytywnej weryfikacji, strona węgierska przekazywała je do obozu, gdzie otrzymywały nową tożsamość. Węgierskim mieszkańcom zabroniono kontaktów z przybyszami i przebywania na terenie bazy. Tłumaczono to zasadami bezpieczeństwa, obowiązującymi w regionie przygranicznym. Według informacji zebranych przez jugosłowiańską policję kadra zarządzająca obozem kontaktowała się zaledwie z kilkoma osobami z zewnątrz, upoważnionymi przez władze ${ }^{20}$.

Pierwsi mieszkańcy obozu, około dwudziestu mężczyzn, przeważnie pracowali w polu. Ich zadaniem było także wyremontowanie pobliskich budynków, aby nadawały się do prowadzenia działalności szkoleniowej. Kadrę obozową stanowili wówczas, oprócz G. Perčeca, Stjepan Petrović, Marijan Mađerić, Dragutin Sikirica i Ivan Mraz, którzy najczęściej byli dezerterami z armii jugosłowiańskiej ${ }^{21}$. Jak pisał były pułkownik armii austrowęgierskiej i działacz ustaszowski Ivan Perčević, na samym początku funkcjonowania obozu G. Perčec stanął przed koniecznością ściągnięcia jeszcze większej liczby osób, tak aby zapewnić ekonomiczne przetrwanie bazy, to $\mathrm{z}$ kolei utrudniało rozwijanie działalności szkoleniowo-dywersyjnej ${ }^{22}$. Istotnie, sytuacja bytowa w obozie była zła. Żyjący tam mężczyźni pracowali bez zapłaty, mieszkali w fatalnych warunkach, co prowokowało bunty przeciwko dowódcy. Sam komendant miał często nadużywać przemocy względem podwładnych, ci z kolei skarżyli się na niego A. Paveliciowi oraz władzom węgierskim ${ }^{23}$. Według raportów policji jugosłowiańskiej, mieszkańcy obozu byli podzieleni na kadrę sprzyjającą G. Perčecowi i tych, którzy pracowali na roli, byli przygotowywani do działań bojowych i jednocześnie domagali się poprawy warunków bytowych. Aby uspokoić napiętą atmosferę, dowództwo musiało nawet wezwać na pomoc policję węgierską ${ }^{24}$. W grudniu 1931 r. najbardziej niezadowolonych wyekspediowano do Włoch lub przerzucono do innych części Węgier, gdzie działali jako współpracownicy węgier-

20 Hrvatski Državni Arhiv, 145.2 (Savska banovina. Odjeljak upravnog odjeljenja za državnu zaštitu), Zagreb (dalej HDA, SB), teczka 105 (02.01.1933).

21 B. Krizman, Ante Pavelić, s. 81-84, 102.

22 Hrvatski Državni Arhiv, 1561 (Služba državne sigurnosti, Republički sekretarijat za unutrašnje poslove Socijalističke Republike Hrvatske) (dalej: HDA, SDS-RSU), teczka 013.0.53 (I. Perčević).

23 HDA, SB, teczka 105 (02.01.1933).

24 M. Basta, Rat je završen 7 dana kasnije, Ljubljana 1962, s. 32. 
skich służb wywiadowczych ${ }^{25}$. Od tamtej pory, w celu poprawienia morale, do obozu starano się kierować odpowiednio zmotywowanych politycznie imigrantów i jednocześnie ograniczyć napływ osób z rejonu przygranicznego, które często były uznawane za zbyt niepewne w sensie ideologicznym. G. Perčec zamieszkał w tym okresie w Budapeszcie, a do bazy przybywał wyłącznie na kontrole. Na stałe w Janka-Puszta osiadł dopiero w połowie 1932 r., w tym samym czasie przybywali kolejni działacze chorwaccy, którzy zasilali kadrę obozową ${ }^{26}$. Na początku 1933 r. w Janka-Puszta pojawiły się osoby wprawione w działalności konspiracyjnej oraz terrorystycznej, prowadzonej przeciwko Jugosławii. Byli wśród nich Zvonimir Pospišil, Stjepan Kopčinović czy Emil Lahovski. Przybywali z Jugosławii, Austrii, kilku było związanych ze środowiskami emigracyjnymi z Ameryki Południowej ${ }^{27}$. Wraz z nimi do obozu trafiło więcej uzbrojenia, głównie broń palna i materiały wybuchowe, potrzebne do wyrabiania bomb, a także stawiacze min. W 1933 r. na terenie bazy znaleźli się także doświadczeni w działalności terrorystycznej działacz bułgarskiej VMRO Vlado Černozemski (prawdziwe nazwisko: Veličko Dimitrov Kerin) oraz Kiril Drangov (prawdziwe nazwisko: Gligor Milčinov) ${ }^{28}$.

Jak wynika z raportu przygotowanego przez naczelnika przygranicznego jugosłowiańskiego kotaru Koprivnica (17 X 1932), po koniec 1932 r. w bazie przebywało 42 imigrantów, którzy byli skoszarowani i nadzorowani w wojskowy sposób. W tym okresie, w następstwie fiaska planów zorganizowania powstania w Lice (6-7 IX 1932), przy akceptacji władz węgierskich i włoskich dowództwo ustaszy postano-

25 O środowisku związanym z Janka-Puszta, które w 1934 r. pozostało na Węgrzech, piszą m.in.: G. Karlić, V. Aralica, Life and work of Vjekoslav Maks Luburić until the proclamation of the Independent State of Croatia, Radovi Zavoda za povijesne znanosti HAZU u Zadru 58 (2016), s. 309-358.

26 V. Šadek, Logor i razvoj ustaške organizacije u Podravini do 1934, Podravina: časopis za multidisciplinarna istraživanja 11 (2012), nr 21, s. 49. Jak wynika z raportu E. Contiego z 1934 r., w blisko sześćdziesięcioosobowej grupie aktywni byli także emisariusze polityczni, którzy podróżowali po całym kraju i wyjeżdżali za granicę w celu werbunku oraz popularyzacji haseł ruchu. Przypuszczalnie liczba osób, stale przebywających na miejscu nie przekraczała pięćdziesięciu; ACS, Carte Conti; por. B. Krizman, Ante Pavelić, s. 213-214.

27 Na początku 1932 r. do Janka-Puszta skierowano m.in. ustaszy odpowiedzialnych za serię zamachów na pociągi, kursujące pomiędzy Austrią a Jugosławią (lato i jesień 1931). Władze jugosłowiańskie odpowiedziały zawieszeniem ruchu kolejowego i zażądały od Austrii usunięcia grup oskarżanych o terroryzm na kolei, co też nastąpiło; V. Vinaver, Svetska ekonomska kriza u Podunavlju u nemački prodor 1929-1934, Beograd 1987, s. 71. 
wiło stworzyć w Janka-Puszta pierwszorzędną bazę operacyjną dla działań terrorystycznych oraz sabotażowych na obszarze jugosłowiańskim. Na początku $1933 \mathrm{r}$. w obozie poprawily się warunki życia, mieszkańcy otrzymali jednolite umundurowanie i rozpoczęli regularne szkolenia w strzelaniu, które naprzemiennie prowadzili Emil Lahovski, Stjepan Kopčinović oraz Zvonimir Pospišil. Sam Z. Pospišil szkolił także podkomendnych w konstruowaniu min. Oprócz G. Perčeca obóz był wizytowany przez samego A. Pavelicia, który kontrolował jakość szkolenia wojskowego ${ }^{29}$.

W latach 1931-1933 z Janka-Puszta nadzorowano akcje dywersyjne i zamachy bombowe przeciwko Jugosławii, a także rozwijano sieć powiązań ze środowiskami chorwackimi, żyjącymi po drugiej stronie granicy. Początkowo głównymi wykonawcami tych zadań byli miejscowi Chorwaci, mieszkający w rejonie rozciągającym się wzdłuż rzeki Drawa (Podravina i Prekodravlje). Najczęściej byli to drobni właściciele ziemscy lub członkowie rodzin rolniczych, których ziemie znajdowały się, w następstwie porozumienia pokojowego z Trianon, po dwóch stronach linii granicznej ${ }^{30}$. Aby mieć kontrolę nad swoją własnością, regularnie i najczęściej nielegalnie przekraczali oni granice, co stanowiło duży problem dla władz węgierskich oraz jugosłowiańskich. Ośrodek ustaszowski wykorzystywał miejscowych łączników do szmuglowania na teren jugosłowiański broni i materiałów propagandowych. Prowadzenie takiej nielegalnej komunikacji było ułatwione przez topografię tego obszaru. Granica państwowa biegła przeważnie rzeką Drawą, która meandrując, uniemożliwiała skuteczny dozór ze strony służb państwowych. Kluczowy dla aktywności obozu w Janka-Puszta był niewielki, położony wzdłuż rzeki rejon o nazwie Prekodravlje, w okolicach miejscowości Ferdinandovac. Na podstawie współpracy z kilkoma tamtejszymi rodzinami zdołano stworzyć trasę przerzutową dla emisariuszy i zamachowców, kierowanych z Węgier na teren Jugosławii.

Ocenia się, że w latach 1931-1934 w rejonie Fernadinovca i miejscowości Novo Virje działało blisko 25 osób, które były wykorzystywane do przenoszenia broni, amunicji, materiałów wybuchowych ${ }^{31}$. Oczywiście region ten był wykorzystywany przez antyjugosłowiańsko nastawione środowiska chorwackie także i we wcześniejszym okresie, głównie z myślą o dostarczaniu broni wykorzystywanej w akcjach

29 HDA, SDS-RSU-1561, 013.14 (Ustaški aparat na Kotaru Koprivnica), 013.2 (Materiali o Janka pusti). Obóz w Janka-Puszta odwiedzał także, prawdopodobnie przed 1933 r., Mile Budak podczas podróży do Czechosłowacji w charakterze agitatora ruchu ustaszy; ACS, Carte Conti.

30 Por. A. Hornjak, Susreti i sukobi, s. 66-67.

31 M. Jareb, Ustaško-domobranski pokret, s. 215-246. 
przeciwko przedstawicielom Królestwa SHS, jednostkom wojska czy żandarmeriii ${ }^{32}$. W szczególności znaczenie Prekodravlja wzrosło jednak w następstwie fiaska powstania w Lice (1932), które ustasze starali się zainicjować, atakując terytorium jugosłowiańskie od strony włoskiego Zadaru. Po pacyfikacji tych wydarzeń przez siły jugosłowiańskie, węgierski obszar przygraniczny, wraz z ośrodkiem w Janka-Puszta, stał się kluczowy dla podtrzymania i rozwijania kontaktów pomiędzy ustaszami przebywającymi za granicą a ich sympatykami z Jugosławii ${ }^{33}$. Zadanie zorganizowania sieci kontaktów we współpracy z tzw. podwójnymi właścicielami należało do trzech braci Domitroviciów, którzy mieszkali po węgierskiej stronie granicy i mieli powiązania z węgierskim wywiadem wojskowym. Początkowo akcjami na tym obszarze, z udziałem współpracowników obozu, koordynował Ivan Domitrović, ale pod koniec 1931 r. został on usunięty z obozu wraz z kilkuosobową grupą „buntowników"34.

I tak, w grudniu 1932 r. współpracownicy obozu przeprowadzili zamachy na budynek serbskiej cerkwi prawosławnej i siedzibę okręgu wojskowego w Zagrzebiu. Jak ustalono podczas śledztwa, materiały wybuchowe pochodziły z Janka-Puszta. 30 VII 1933 r. bomba zniszczyła część stacji kolejowej w Koprivnicy, a we wrześniu ładunek eksplodował w arsenale broni w przygranicznej miejscowości Gola. Zamach na stacji kolejowej był dziełem przypadku, pierwotnie bomba miała dotrzeć pociągiem do Belgradu i być wykorzystana do zamordowania przewodniczącego trybunału obrony państwa Dragana Bubnja. Pakunek wzbudził jednak zaniepokojenie urzędników kolejowych. Eksplodował przy próbie rozpakowania, zabijając policjanta i ciężko raniąc dwie osoby ${ }^{35}$. Fiaskiem zakończył się także plan zamordowania przez wysłanników z obozu bana banowiny sawskiej Iva Perovicia (1882-1958), 1 XII 1933 r. Zamach planowano przeprowadzić podczas obchodów państwowo-religijnych w cerkwi w Zagrzebiu, ustasze Stjepan Petrović i Andrija Grediček uznali jednak, że nie udałoby im się bezpiecznie opuścić miejsca zamachu. Mieli przy sobie osiem bomb, które odebrali na granicy węgierskiej od łączników z obozu. Po tych

\footnotetext{
32 M. Basta, Rat je završen, s. 36. Kalendarium akcji terrorystycznych, przeprowadzonych przez ustaszy przed zamachem marsylskim (1929-1934): B. Krizman, Ante Pavelić, s. 211-212.

33 Sam G. Perčec był właścicielem niewielkiej parceli nad Drawą nieopodal Ferdinandovca, gdzie przed okresem dyktatury Aleksandra I utrzymywał się m.in. z połowu ryb i rozwijał kontakty z miejscowymi Węgrami; Ž. Krušelj, U žrvnju državnog terora i ustaškog terorizma, Koprivnica 2001, s. 60-61.

34 HDA, SDS-RSU-1531, 013.15 (Ustaški aparat na Kotaru Đurđevac) (Ignac Domitrović).

35 B. Krizman, Ante Pavelić, s. 131, 210.
} 
perypetiach skierowali się przez granicę do Janka-Puszta, gdzie w kwietniu 1934 r. zostali oskarżeni o zdradę i rozstrzelani ${ }^{36}$. W tym samym czasie policja jugosłowiańska rozpracowała także i rozbiła sieć współpracowników bazy w Jugosławii. W rezultacie władze węgierskie podjęły decyzję o likwidacji ośrodka ze względu na jego dekonspirację ${ }^{37}$.

Strona węgierska tolerowała działalność obozu, ale zazwyczaj była sceptycznie nastawiona do inicjowanych tam akcji. Obawiano się, że doprowadzą one do zaostrzenia i tak napiętej sytuacji na granicy oraz sprowokują władze jugosłowiańskie do protestów na forum dyplomatycznym, co też nastąpiło na początku 1934 r., gdy Jugosławia skierowała przeciwko Węgrom skargę do Ligi Narodów. Zanim członkowie specjalnie powołanej komisji międzynarodowej przybyli w maju 1934 r. do Janka-Puszta, wywieziono stamtąd przebywające wcześniej osoby, rozlokowując je w kilku zakonspirowanych miejscach w południowych Węgrzech (Nagykanizsa, Surdupuszta, Anapuszta, Buzupuszta, Langsnok $)^{38}$. Sam G. Perčec opuścił Węgry na rozkaz Ante Pavelicia, który uznał go za głównego winowajcę dekonspiracji. Zginął rok później, najprawdopodobniej na polecenie poglavnika ${ }^{39}$.

Należy podkreślić, że właściwa dekonspiracja obozu Janka-Puszta nastąpiła już w październiku-listopadzie 1933 r., po serii publikacji, które ukazały się na łamach zagrzebskiej gazety „Novosti”. Ich autorką była współpracowniczka jugosłowiańskiego wywiadu Jelka Pogorelec, która przebywała w Janka-Puszta i prywatnie była związana z G. Perčecem. Do współpracy miał ją przekonać inspektor tajnej policji jugosłowiańskiej Vladeta Miličević. Na podstawie tych publikacji władze jugosłowiańskie wkrótce sfinansowały i wydały broszurę pt. Sekrety emigranckich złoczyńców (Tajne emigrantskih zločinaca), którą następnie przetłumaczono i rozpowszechniano w Europie ${ }^{40}$. J. Pogorelec opisywała w niej trudne warunki życia osób osadzonych

36 HDA, SDS-RSU-1561, 013.2 (Materiali o Janka pusti); Ž. Krušelj, U žrvnju državnog terora, s. 23-25.

37 B. Krizman, Ante Pavelić, s. 214; Ž. Krušelj, U žrvnju državnog terora, s. 233.

38 M. Basta, Rat je završen, s. 33.

39 G. Perčec został odsunięty od zarządzania obozem tuż po ukazaniu się publikacji prasowych na temat Janka-Puszta. Jego następcami byli: w 1933 r. Božo Papić, a następnie, zgodnie z decyzją A. Pavelicia, Vjekoslav Servatzy, który przyjechał z Włoch. On też stał się najważniejszą osobą, reprezentującą ruch ustaszy na Węgrzech; M. Basta, Rat je završen, s. 33; B. Krizman, Ante Pavelić, s. 103-105. W tym samym czasie V. Servatzy stworzył dwa „zapasowe” ośrodki szkoleniowe w Baza-puszta ( $25 \mathrm{~km}$ od granicy) i Nagykanizsa; M. Jareb, Ustaško-domobranski pokret, s. 247-256.

40 J. Pogorelec, Tajne emigrantskih zločinaca. Ispovijest Jelke Pogorelec o Gustavu Perčecu 
w obozie. Według jej relacji dowództwo skoszarowało i odizolowało podwładnych od kontaktów z otoczeniem, a także zmuszało do ciężkiej pracy fizycznej oraz stosowało przemoc. W pierwszej części dnia członkowie obozu pracowali na polu, po południu i wieczorem uczestniczyli w spotkaniach propagandowych oraz uczyli się obsługiwać broń, którą według J. Pogorelec przysyłano z Włoch. Wiarygodność tego przekazu była podważana m.in. przez węgierskiego pułkownika Tattaya, który $\mathrm{z}$ ramienia władz był w kontakcie z dowódcami obozu. Jego zdaniem J. Pogorelec nie mogła orientować się w sprawach obozu, ponieważ na co dzień mieszkała w Budapeszcie. Informacje o bazie mogła zdobyć przy okazji zaledwie kilku odwiedzin. Zdaniem węgierskiego oficera było wątpliwe, aby G. Perčec pozwolił J. Pogorelec wnikać w szczegółowe kwestie dotyczące funkcjonowania ośrodka ${ }^{41}$.

Pół roku po likwidacji obozu Janka-Puszta osoby, które wcześniej tam przebywały i były szkolone, przeprowadziły udany zamach na króla jugosłowiańskiego Aleksandra I i francuskiego ministra spraw zagranicznych Louisa Barthou (9 X 1934). W siedmioosobowej grupie zamachowców znaleźli się byli członkowie kadry obozowej: Mijo Bžik, Mijo Kralj (Mijo Babić), Ivan Rajić i Zvonimir Pospišil. Do króla i ministra strzelał działacz macedoński Vlado Černozemski (w Marsylii legitymował się czechosłowackim paszportem na nazwisko Kelemen), który wcześniej także przebywał na terenie obozu ${ }^{42}$. Francuskie gazety szybko powiązały zamachowca

i drugovima, koji u tuđoj službi rade protiv vlastite domovine grozote na Janka Puszti, Zagreb 1933. Francuska wersja: tenże, Les secrets des organisations terroristes au service du révisionnisme, Paris 1934.

41 P. Hamerli, Croatian political refugees, s. 54. Z relacji węgierskiego pułkownika wynikało, że obóz miał charakter wyłącznie szkoleniowy. O jego zmilitaryzowanym charakterze miała według niego świadczyć tylko obecność dwóch osób wcześniej związanych z armią habsburską: Gustava Perčeca i Vjekoslava Servatzyego.

42 Ž. Krušelj, U žrvnju državnog terora, s. 157-159. Selekcji zamachowców miał dokonywać były komendant obozu Janka-Puszta i zaufany współpracownik A. Pavelicia V. Servatzy, któremu nakazano wybrać osoby, spełniające „najwyższe kryteria moralne i bojowe”. Mijo Bžik (ur. 1907 w Koprivnicy) pojawił się na Węgrzech, gdy w Jugosławii skazano go na 18 miesięcy więzienia za współudział w przygotowywaniu aktów terrorystycznych. W obozie Janka-Puszta znalazł się w lutym 1933 r., wraz z Mijo Kraljem. Zvonimir Pospišil uciekł z Jugosławii na Węgry w 1929 r., jako skazany na śmierć za organizowanie zabójstw politycznych. W kwietniu 1934 r. mieszkał w Budapeszcie i miał dobre relacje zarówno ze stronnikami G. Perčeca, jak i z władzami węgierskimi. Niewiele natomiast wiadomo o losach Ivana Rajicia; ACS, Carte Conti; por. B. Krizman, Ante Pavelić, s. 212-214. W historiografii węgierskiej pokutuje mylny pogląd, że G. Černozemski nie uczestniczył w zamachu marsylskim, jako że informacje o jego pobycie na Węgrzech urywają się na 1932 r.; por. P. Hamerli, Croatian political refugees, s. 643. 
z obozem w Janka-Puszta. Sięgnięto po informacje zawarte w publikacji J. Pogorelec i oskarżano Węgry o wspieranie terrorystów. Zdaniem stałego przedstawiciela Węgier przy Radzie Ligi Narodów Zoltána Baranyai władze węgierskie odpowiadały co najwyżej za to, że nie wyciągnęły odpowiednich wniosków ze spotkań, które chorwaccy imigranci odbywali w budapeszteńskich kawiarniach, oraz z artykułów, które publikowali na łamach swojej prasy. Dyplomata zaprzeczał, jakoby Węgry prowadziły szkolenia wojskowe dla osób przebywających w obozie Janka-Puszta bądź zaopatrywały je w broń. Z kolei ówczesny premier węgierski podkreślał, że Węgry udzielały jedynie schronienia uchodźcom i nie były zamieszane ani w przygotowanie, ani przeprowadzenie zamachu. Apelował, żeby oddzielić kwestię węgierskiej „pomocy humanitarnej" udzielanej uchodźcom od jakichkolwiek inspiracji politycznych, wymierzonych w Jugosławię czy Francję ${ }^{43}$. Jak przekonywał w Genewie na początku grudnia 1934 r. wysłannik węgierskiego rządu Tibor Eckhardt, Janka-Puszta nigdy nie służyła do celów wojskowych, była jedynie „niewielkim gospodarstwem rolnym”, w którym przebywało od dwudziestu do trzydziestu chorwackich imigrantów. Większość opuściła to miejsce dobrowolnie, bez nacisku ze strony władz węgierskich, udała się do innych miejscowości lub wyjechała za granicę ${ }^{44}$.

Obóz w Janka-Puszta, który stanowił najważniejszy element powiązań i działalności ustaszy na obszarze Węgier, był dla tamtejszych władz kłopotliwy od samego początku istnienia. Węgry były krajem rewizjonistycznym, ale otoczonym przez państwa-beneficjentów porządku wersalskiego opierające się na autorytecie i wpływach Francji. W celu podtrzymania stabilnej pozycji międzynarodowej władze węgierskie musiały prowadzić elastyczną i jednocześnie wyważoną politykę względem sąsiadów. Tolerowanie na swoim terytorium ośrodka szkoleniowego i sabotażowo-dywersyjnego niosło za sobą spore ryzyko polityczne i w rezultacie doprowadziło do znaczącego zachwiania pozycji międzynarodowej państwa. Najbardziej negatywne dla Węgier konsekwencje działalności obozu dały o sobie znać w następstwie zamachu marsylskiego, którego ofiarą był także francuski minister spraw zagranicznych. Ostatecznie tylko Węgry zostały obarczone na forum Ligi Narodów odpowiedzialnością za wspieranie terroryzmu. Włochy uniknęły tych oskarżeń, choć były w wówczas głównym sponsorem organizacji ustaszy ${ }^{45}$.

43 ASD AP 1930-1945, Jugoslavia, teczka 55 (02.22.1934).

44 Tibor Eckhardt's great speech before the Council of The Laague of Nations, Danubian review 1 (1934), nr 7, s. 6-7.

45 J. Paszkiewicz, Jugosławia w polityce Włoch, s. 57-59. 
Bez wątpienia Węgry stanowily newralgiczny obszar aktywności ruchu ustaszy w początkowym okresie jego istnienia. Ante Pavelić poszukiwał tam środków finansowych, zaplecza organizacyjnego i kadrowego. Uważał, że oparcie się na współpracy z węgierskimi kołami polityczno-wojskowymi byłoby dobrym rozwiązaniem ze względu na wspólne dla obu stron antyjugosłowiańskie nastawienie oraz tradycje współpracy sięgające czasów austrowęgierskich. W rezultacie, wykorzystując terytorium węgierskie, udało się stworzyć ważną bazę przerzutową dla ludzi, broni i propagandy kierowanych na terytorium jugosłowiańskie, ugruntować szlaki komunikacyjne (przemytnicze), wyszkolić kadrę organizacji i udoskonalić działalność terrorystyczno-dywersyjną. Poważnym ograniczeniem dla kontynuowania tych działań był jednak brak jednoznacznych deklaracji wsparcia ze strony władz węgierskich, co ostatecznie popchnęło ustaszy w stronę Włoch. W rezultacie, w latach 1931-1934 rewizjonistyczne Węgry odgrywały ważną, ale komplementarną rolę w strategii tego ruchu, który w sensie programowym, organizacyjnym czy militarnym znalazł się pod wpływami włoskimi. Kontrola ta zacieśniła się w latach 1934-1939, gdy ustasze znaleźli się w pełnej izolacji, w następstwie skandalu międzynarodowego po zamachu marsylskim i podejrzeń o współpracę z Niemcami. Na Węgrzech A. Pavelić nie zdołał przekonać do siebie wszystkich środowisk imigranckich, podejrzewał zresztą, że spora ich część była infiltrowana przez służby jugosłowiańskie. Nie udało się także powstrzymać dekonspiracji bazy z Janka-Puszta, pomimo prób izolowania jej mieszkańców i bywalców od otoczenia. Po ujawnieniu informacji o obozie i wyeliminowaniu przez służby jugosłowiańskie jego współpracowników, działających po drugiej stronie granicy, znacząco osłabła rola Podraviny oraz Prekodravlja jako obszarów kontaktowych. Władze jugosłowiańskie skutecznie spacyfikowały proustaszowskie sympatie wśród tamtejszej ludności i wzmocniły kontrolę granicy.

\section{Bibliografia}

\section{Źródła archiwalne i publikowane}

Archivio Centrale dello Stato, Ispettore Generale di Pubblica Sicurezza, Carte Conti (Rzym).

Archivio Storico Diplomatico del Ministero degli Affari Esteri, Roma, Affari Politici 1919-1930 (Rzym).

Hrvatski Državni Arhiv (Zagrzeb), 145.2 (Savska banovina. Odjeljak upravnog odjeljenja za državnu zaštitu), 
1561 (Služba državne sigurnosti, Republički sekretarijat za unutrašnje poslove Socijalističke Republike Hrvatske

Documenti Diplomatici Italiani, VII seria, Roma 1967-1975.

\section{Opracowania}

A horvát-magyar együttélés fordulópontjai. Intézmények, társadalom, gazdaság, kultura, red. P. Fodor, D, Šokčević, J. Turkalj, D. Karbić, Budapest 2015.

Bartulin N., The Racial idea in the Independent State of Croatia, Leiden-Boston 2014. Basta M., Rat je završen 7 dana kasnije, Ljubljana 1962.

Gobetti E., Dittatore per caso: un piccolo duce protetto dall'Italia fascista, Napoli 2001. Hamerli P., Croatian political refugees living in emigration in the interwar period: the case of the Croatian political refugees in Hungary, Hungarian Historical Review 6 (2017), nr 3, s. 624-646.

Hamerli P., The Hungarian-Italian support of the Croatian separatism between 1928 and 1934, West Bohemian Historical Review 5 (2015), nr 1, s. 51-76.

Heka L., Hrvatsko-ugarski odnosi od srednjega vijeka do Nagodbe iz 1868. s posebnim osvrtom na pitanje Slavonije, Scrinia Slavonica. Godišnjak Podružnice za povijest Slavonije, Srijema i Baranje 8 (2008), s. 152-173.

Hornjak A., Susreti i sukobi. Ogledi o srpsko-madarskim odnosima, Beograd 2017.

Jareb J., Šest dokumenata o prvom dodiru dra Ante Pavelića s talijanskom vladom 1927, Hrvatska revija 4 (1970), s. 1165-1178.

Jareb M., Ustaško-domobranski pokret od nastanka do travnja 1941. godine, Zagreb 2006.

Krizman B., Ante Pavelić i ustaše, Zagreb 1986.

Krušelj Ž., U žrvnju državnog terora i ustaškog terorizma, Koprivnica 2001.

Matković S., Prilozi za politički životopis Ive Franka i evoluciju pravaštva, Časopis za suvremenu povijest 40 (2008), nr 3, s. 1067-1086.

Ormos M., Merénylet Marseille-ben, Budapest 1984.

Paszkiewicz J., Jugosławia w polityce Włoch w latach 1914-1941, Poznań 2004.

Paszkiewicz J., Terrorism in service of the Croatian independence. The international connections of the Croatian separatists (1929-1941), [w: ] Europa Środkowa i Bałkany. Konteksty historyczne i politologiczne, red. M. Korzeniewska-Wiszniewska, A. Kastory, R. Woźnica, Kraków 2019, s. 343-359.

Pogorelec J., Les secrets des organisations terroristes au service du révisionnisme, Paris 1934. 
Pogorelec J., Tajne emigrantskih zločinaca. Ispovijest Jelke Pogorelec o Gustavu Perčecu i drugovima, koji u tuđoj službi rade protiv vlastite domovine grozote na Janka Puszti, Zagreb 1933.

Šadek V., Logor i razvoj ustaške organizacije u Podravini do 1934, Podravina: časopis za multidisciplinarna istraživanja 11 (2012), $\mathrm{nr} 21$, s. 47-56.

Sokcsevits D., Horvátország a 7. századtól napjainkig, Budapest 2011.

Tibor Eckhardt's great speech before the Council of The Laague of Nations, Danubian review 1 (1934), nr 7, s. 6-7.

Vinaver V., Jugoslavija i Mađarska 1918-1933, Beograd 1977.

Vinaver V., Svetska ekonomska kriza u Podunavlju u nemački prodor 1929-1934, Beo$\operatorname{grad} 1987$.

\section{Summary}

Hungary's role in the activity of the Ustasha - Croatian Revolutionary Movement (1929-1934)

Hungary played a vital albeit ambivalent role at the beginning of the Ustasha movement (1929-1934). Efforts were made to establish the cadre organisation framework in the Hungarian territory; support was sought of the Croatian migrant communities and task groups trained in diversion and terrorist tactics. They mainly operated in the south of the country; the diversion-training headquarters were located in Janka-Puszta (1931-1934). It was from there that the Ustasha networked in the border areas (Podravina, Prekodravlje) in order to smuggle people, arms and propaganda materials into Yugoslavia. In spite of the clandestine nature of the organisation, the movement was disclosed which led to a decision of the Hungarian authorities to dispose of all the Ustasha structures in the country in 1934, after a series of accusations of supporting anti-Yugoslav terrorism. As a result, Hungary was no longer a strategic asset for the Ustasha movement which subsequently migrated under the nearly complete control of fascist Italy.

Translated by Ewa Dratwa

Nadesłany: 19 IV 2021

Nadesłany po poprawkach recenzyjnych: 15 VI 2021

Zaakceptowany: 31 VI 2021 
Dr hab. Jędrzej Paszkiewicz, prof. UAM

Uniwersytet im. Adama Mickiewicza w Poznaniu

Wydział Historii

ul. Uniwersytetu Poznańskiego 7

61-614 Poznań

e-mail:prosinac@amu.edu.pl 